\title{
Wildlife Mortality Investigation and Disease Research: Contributions of the USGS National Wildlife Health Center to Endangered Species Management and Recovery
}

\author{
Christopher J. Brand \\ U.S. Geological Survey, National Wildlife Health Center, 6006 Schroeder Rd., Madison, WI 53711
}

\begin{abstract}
The U.S. Geological Survey-National Wildlife Health Center (NWHC) provides diagnostic services, technical assistance, applied research, and training to federal, state, territorial, and local government agencies and Native American tribes on wildlife diseases and wildlife health issues throughout the United States and its territories, commonwealth, and freely associated states. Since 1975, > 16,000 carcasses and specimens from vertebrate species listed under the Endangered Species Act have been submitted to NWHC for determination of causes of morbidity or mortality or assessment of health/disease status. Results from diagnostic investigations, analyses of the diagnostic database, technical assistance and consultation, field investigation of epizootics, and wildlife disease research by NWHC wildlife disease specialists have contributed importantly to the management and recovery of listed species.
\end{abstract}

Keywords: endangered species, disease, mortality, management, recovery, emerging diseases, diagnostic, vaccination

\section{INTRODUCTION}

Knowledge of morbidity and mortality factors for endangered species and their relative importance and impact on endangered populations is a critical component of understanding the driving forces of species declines and potential for extinction, as well as identifying limiting factors to species recovery. Wilson (1992) identified the major drivers of species imperilment, including: habitat destruction, alien species, pollution, overexploitation, and disease. However, few quantitative studies have been conducted on the roles of factors that threaten species (Wilcove et al. 1998). Infectious diseases have historically seldom been considered to be

Published online: January 14, 2014

Correspondence to: Christopher J. Brand, e-mail: cbrand@usgs.gov potential drivers of the decline of wildlife species to the point of endangerment or extinction (MacPhee and Greenwood 2013). In an examination of the 2004 IUCN Red List of Threatened Species, Smith et al. (2006) found only 25 $(<4 \%)$ of 724 plant and animal species extinctions since 1900 were linked to infectious diseases; and of 2,852 critically endangered species, $223(<8 \%)$ have infectious disease listed as a contributing factor to their endangered status. However, few of these cases were sufficiently studied or documented, and there was little conclusive evidence to support that disease was in fact a contributing factor (Smith et al. 2006). Among the few early studies indicating infectious disease as a primary factor in the decimation of species was Warner's (1968) treatise on the role of introduced avian malaria (Plasmodium relictum) and possibly avian pox in the 
extinction of 16 endemic Hawai' ian forest birds and declines to endangered status of numerous others.

More recently, disease has been increasingly recognized as a major factor in species population declines and extinction as well as being an impediment to recovery of endangered species. Examples include: sylvatic plague (Yersinia pestis; Jachowski and Lockhart 2009), canine distemper virus in black-footed ferrets (Mustela nigripes; Williams et al. 1988), chytridiomycosis in several amphibian species (Schloegel et al. 2006; Skerratt et al. 2007; Daszak et al. 1999), transmissible facial tumor disease in the Tasmanian devil (Sarcophilus harrisii; McCallum et al. 2009). Pedersen et al. (2007) list 31 pathogens causing population declines or reduced fitness in mammals on the 2006 IUCN Red List of Threatened Species. Newly discovered and emerging diseases in wildlife have accounted for many of these cases. Driving forces associated with the exacerbation of the occurrence and impacts of such emerging diseases include introduction of exotic species and their pathogens, pathogen introduction from expanding world commerce and travel, large scale habitat and land-use changes in quality, quantity, and distribution; and climate change. As the impact of disease on imperiled species is being increasingly recognized, so is the need to identify their causes, quantify their impact and demographic role, and develop solutions to aid in preventing their extinction and hastening their recovery.

This paper presents examples and cases of contributions made by the U.S. Geological Survey (USGS) National Wildlife Health Center (NWHC) to the survival and recovery of endangered species through identification and quantification of morbidity and mortality factors, technical assistance on wildlife disease-related issues, field investigation of epizootics, and through research and development to assist wildlife and natural resource managers in disease identification, prevention, and management in endangered species.

\section{The USGS National Wildlife Health Center}

The NWHC is a federal science center established in 1975 under the U.S. Fish and Wildlife Service (USFWS), and later transferred to the USGS. With a mission to “...provide national leadership to safeguard wildlife and ecosystem health through dynamic partnerships and exceptional science," the NWHC provides diagnostic services, technical assistance, applied research, and training to federal, state, territorial, and local government agencies and Native American tribes on wildlife diseases and wildlife health issues throughout the United States and its territories, commonwealth, and freely associated states. Diagnostic and research laboratories and experimental facilities are located in Madison, Wisconsin, with a Honolulu Field Station (HFS) in Honolulu, Hawai'i, to address specific disease issues in Hawai'i and Pacific islands (see www.nwhc.usgs.gov).

\section{Diagnostic Database Supports Management and Regulatory Decisions}

Since its establishment in 1975, the NWHC has conducted necropsies and laboratory studies to determine causes of morbidity, mortality, or health status in $>110,000$ wildlife specimens submitted for diagnosis. Of these, $>16,000$ were species that are, or were formerly, listed under the U.S. Endangered Species Act in the categories of: candidate, threatened, endangered, or delisted in all or part of their range; or listed by the International Union for the Conservancy of Nature (IUCN), or Convention on the International Trade in Endangered Species (CITES). These submissions represented 136 species from all classes of vertebrates (birds $78 \%$, reptiles $11 \%$, mammals $10 \%$. amphibians $2 \%$, fish $<1 \%$ ). The NWHC Diagnostic Database is comprised of information and data from each of the $>110,000$ carcasses or specimens submitted. The database has been used extensively to provide summaries and analyses of status and trends of mortality factors for use in wildlife management and regulatory decisions, including those that involve or affect endangered species. For example, since 1975, >1,200 bald eagle (Haliaeetus leucocephalus) carcasses have been examined at NWHC. Cumulative data from bald eagles have been analyzed periodically and used in major decision-making processes:

\section{Non-toxic Shot Regulations for Waterfowl Hunting}

Lead poisoning in birds from ingesting spent lead shotgun pellets has been known as a major mortality factor in waterfowl since the 1870s (Grinnell 1894). Despite this, it wasn't until the 1970-1980s that significant pressure mounted to require non-toxic shot for waterfowl hunting (USFWS 1976, USFWS 1986, Friend et al. 2009). Part of the impetus for this conversion involved a suit brought about by the National Wildlife Federation to ban the use of lead shot based in part on the increasing number of secondary lead 
poisoning cases in bald eagles from consuming crippled and lead poisoned waterfowl. In an analysis of 1,429 bald eagles necropsied by the NWHC and Patuxent Wildlife Research Center (at that time part of the USFWS) lead poisoning accounted for 52\% of poisoned eagles (USFWS 1986). Later reports from NWHC (Franson et al. 1995; NWHC unpublished) added significantly to these data and were a major contribution to legislation calling for the phase-in and eventual conversion from lead shot to non-toxic shot for waterfowl hunting in the United States in 1991.

\section{Powerline Electrocution}

NWHC diagnostic data from bald and golden (Aquila chrysaetos) eagles were instrumental in identifying the extent of electrocution and traumatic deaths associated with powerlines. Franson et al. (1995) reported that, of 4,300 eagles examined during a 30-year period between the 1960s and 1990 s, $12 \%$ of bald eagles and $25 \%$ of golden eagles died from electrocution, and Thomas (1999) reported numbers of eagle deaths from electrocution during 1975-1997 by state, with the majority of cases occurring in Western states, Alaska, and Florida. These results contributed to cooperative establishment of guidelines by the Edison Electric Institute's Avian Power Line Interaction Committee (APLIC) and the USFWS in the construction and retrofitting design of powerlines to reduce this cause of mortality in eagles and other raptors (APLIC and USFWS 2005).

\section{Pesticide Poisoning}

Cumulative data on bald eagle mortality factors also revealed a relatively high proportion of deaths caused by agricultural pesticides. Franson et al. (1995) reported 139 eagles in 25 states dying from organophosphate (OP) compound and carbamate poisoning. These data, along with data from other wildlife mortality from these pesticides, were used to support restrictions on the use of some OPs and carbamates, including removal of diazinon from use for turf applications and limitations on the use of carbofuran (Glaser 1995).

\section{SUPPORT FOR WiLDLIFE LAW ENFORCEMENT}

Diagnostic examinations are important not only in determining the cause of death (COD) of victims, but also in determining contributing factors that may have led to the COD as well as documenting factors that were not contributing to mortality. Such wildlife necropsies require a comprehensive approach to diagnostic examination supported by an interdisciplinary team of laboratory and pathology support, and prove invaluable when used to support cases of wildlife mortality that involve violation of wildlife laws. The NWHC provides diagnostic support for federal wildlife law enforcement officials in identifying potential cases to pursue and providing legal-quality evidence. A total of 963 carcasses or specimens submitted from listed species were analyzed in support of law enforcement officials, primarily from the USFWS (NWHC unpublished data), largely involving illegal take of Federally protected wildlife under Endangered Species Act, Migratory Bird Treaty Act, Bald and Golden Eagle Protection Act, and Marine Mammal Protection Act.

\section{Field InVestigation OF Epizootics in ENDANGERED SPECIES}

Field investigations of mortality factors in endangered species, integrated with demographic and ecological studies, can provide important information on the relative importance of various mortality factors and impact on endangered populations that can be used to guide management decisions. The Laysan duck (Anas laysanensis), once widely distributed along the Hawai'ian archipelago, has been restricted for the past 150 years to a single population numbering 400-500 birds on Laysan Island (Moulton and Weller 1984; Reynolds and Work 2005). Concern over the risk for extinction of this species led to the translocation of a portion of the population to Midway Atoll in 2004 and 2005 (Reynolds et al. 2008). In November 1993, the occurrence of an unusually large number of Laysan duck carcasses on Laysan Island in the Northwestern Hawai'ian Islands prompted a field investigation of the event by the NWHC HFS. Emaciation complicated by parasitic infection by Echinuria uncinata was diagnosed as the cause of death, and recommendations were made for anthelmintic treatment of infected ducks, particularly those to be translocated in the future (Work et al. 2004). During 1998-2003, in preparation for the translocation, a collaborative study between the USGS Pacific Islands Ecosystems Research Center and the HFS determined mortality rates, body condition, and causes of mortality of Laysan ducks through intensive mark-resighting and recovery of 297 ducks and diagnostic necropsies of carcasses (Reynolds and Work 2005). This study attributed a high duckling mortality $(0.7-0.9)$ to habitat-associated overcrowding and brood separation, leading to duckling trauma and exposure-related 
factors as the major causes of death. Reynolds and Work (2005) provided further habitat management recommendations for this population, as well as information on managing potential habitat-limiting factors that could affect the translocated population. During 2004-2005, following extensive habitat management on Midway, 42 ducks that were treated with ivermectin and tested negative for $E$. uncinata were translocated to Midway Atoll. Since then, this parasite has not been detected in Laysan ducks on Midway. By 2007, Laysan ducks translocated to Midway Atoll increased to an estimated population $>200$ (Reynolds et al. 2008). However, in August 2008, an epizootic was discovered on Midway, prompting a field investigation. Avian botulism (Clostridium botulinum type $\mathrm{C}$ toxin) was diagnosed as the cause of mortality that killed at least 181 adult, fledgling and duckling Laysan ducks (Work et al. 2010). The epidemiological investigation identified the likely site and source of the botulinum toxin as a concrete catchment basin and documented the geographic expansion of mortality to 12 wetlands concurrent with peak dispersal of fledglings on the islands of Midway. Based on this investigation, recommended management options undertaken by the USFWS to control and prevent avian botulism included annual flooding of the concrete catchment basin in summer; draining, sludge removal, and cleaning of the basin during fall and winter months; vegetation removal around wetlands to facilitate carcass detection; and increased frequency of searches to detect sick and dead birds, especially during summer months (Reynolds et al. 2011). The effect of these management actions on reducing mortality from avian botulism cannot be directly determined. Botulism recurs on Midway, but not at the magnitude of the outbreak in 2008. However, Laysan ducks on Midway increased to $>400$ in 2010.

\section{DEVELOPMENT OF VACCINES FOR ENDANGered SpeCIes}

The use of commercial vaccines to prevent disease in freeliving endangered species has received increasing attention in programs, for example, to prevent rabies in Ethiopian wolves (Canis simensis; Randall et al. 2004; Stewart 2009), West Nile virus in California condors (Gymnogyps californianus; Chang et al. 2007), and a measles-like respiratory disease in mountain gorillas (Gorilla beringei beringei; Ryan and Walsh 2011). Advances in recombinant DNA technology and other new vaccine technologies have expanded the opportunities to develop safer and more efficacious vaccines specific for wildlife species and suitable for mass distribution to free-living wildlife (Rupprecht et al. 2004). The NWHC has developed and tested vaccines that have been used in management plans for several endangered species. In a collaborative study with USGS Patuxent Wildlife Research Center (PWRC), Olsen et al. (2009) studied the serological response of sandhill cranes (Grus canadensis) to vaccination against West Nile virus (WNV) using a commercial equine inactivated vaccine. Vaccinated sandhill cranes responded with higher titers to WNV and had viremias for shorter periods of time than controls; unvaccinated cranes also had lesions in the brain and brain stem after challenge, whereas vaccinated cranes did not (Olsen et al. 2009). While this vaccine was not tested specifically in whooping cranes (G. americana), demonstration of its protection against WNV in surrogate sandhill cranes resulted in the decision to vaccinate whooping cranes raised at PWRC and at the International Crane Foundation (ICF), Baraboo, Wisconsin, as part of their health checks and preparation for reintroduction to establish a new Florida population. Whooping cranes are also vaccinated against eastern equine encephalitis prior to reintroduction as a result of separate studies at PWRC using an inactivated human vaccine against Eastern Equine Encephalitis (Carpenter et al. 1992; Olsen et al. 1997).

\section{Vaccination of Black-Footed Ferrets and Prairie Dogs Against Plague}

Black-footed ferrets and prairie dogs (Cynomys spp.) are highly susceptible to sylvatic plague (Yersinia pestis), and this disease is considered one of the major impediments to recovery of the endangered black-footed ferret (Jachowski and Lockhart 2009) as well as the threatened Utah prairie dog (C. parvidens; USFWS 2009). Antolin et al. (2002) provide a synopsis of the plight of black-footed ferrets and the role and impact of plague on ferrets and prairie dogs, and Abbott et al. (2012) summarize NWHC's role in the development and testing of two vaccines against plague, one for ferrets and one for prairie dogs, that are currently being deployed. To protect captive-born black-footed ferrets from plague upon release, the NWHC tested an injectable protein vaccine ( $\mathrm{F} 1$ and $\mathrm{V}$ antigens of $Y$. pestis), developed by the U.S. Army Medical Research Institute of Infectious Disease (Powell et al. 2005) in experimental studies. Vaccinated ferrets developed significant antibody titers against $\mathrm{F} 1$ and $\mathrm{V}$ which lasted more than 3 years, and 
survived challenge with virulent $Y$. pestis by both subcutaneous injection and oral routes (Rocke et al. 2008). This F1/ $\mathrm{V}$ vaccine is now being administered to all captive-born black-footed ferrets prior to release as well as to wildcaught ferrets at some locations. In a study in Montana, Matchett et al. (2010) and Biggins et al. (2010) demonstrated that survival of released ferrets that were vaccinated against plague was significantly greater than that of unvaccinated ferrets that were released. The F1/V vaccine has also been deployed to protect free-living ferrets in the face of a plague outbreak in prairie dogs in the Conata Basin of South Dakota (Livieri 2013).

While vaccination with the $\mathrm{F} 1 / \mathrm{V}$ vaccine may prevent plague in individual ferrets, prairie dogs remain subject to plague epizootics that can cause $>90 \%$ mortality, thus almost eliminating the ferret's prey base. To prevent plague in prairie dogs, the NWHC, in partnership with the University of Wisconsin School of Veterinary Medicine, developed and tested (for efficacy, safety, duration of immunity, reproduction effects and efficacy, and safety in non-target species) a recombinant vaccine against plague using a raccoon pox-vector (RCN) to express the F1 and Vt antigens (Rocke et al. 2010). The RCN-F1-Vt vaccine has been incorporated into an oral bait matrix that is highly palatable to prairie dogs, along with rhodamine $\mathrm{B}$ as a biomarker for animals consuming the bait. Initial field trials of this vaccine in 2012 to determine safety in the field and rates of bait consumption and immune response to vaccination demonstrated a high rate of bait uptake within the first $48 \mathrm{~h}$ (Rocke, personal communication). Further field trials will continue in 2013 in prairie dog colonies in 8 western states. If successful, oral vaccination of prairie dogs against plague will be an additional tool that can be used to enhance the recovery of the black-footed ferret as well as the threatened Utah prairie dog.

\section{Disease and Health Considerations in Captive Breeding, Translocations, and Reintroduction of Endangered Species}

Breed et al. (2009) discuss the importance of disease considerations in the captivity, translocation, and reintroduction of endangered wildlife. Input of wildlife disease specialists is an important part of this process; as well as active health and disease monitoring, including postmortem examinations. NWHC staff have been involved in endangered species recovery teams and their working groups in the planning and risk assessment, disease monitoring, and clinical examinations for numerous endangered species recovery programs involving captive breeding, translocation and reintroduction, such as for the masked bobwhite (Colinus virginianus ridgwayi), blackfooted ferret, Puerto Rican parrot (Amazona vittata), whooping crane, néné (Branta sandvicensis), Nihoa honeycreeper (Telespyza ultima), palila (Loxioides bailleui), and Laysan duck.

\section{Pathogen Discovery: New Diseases IDENTIFIED IN ENDANGERED SPECIES}

The International Crane Foundation (ICF) is a non-governmental conservation organization located in Baraboo, Wisconsin, dedicated to conservation of the world's cranes and their habitats. The ICF partners with federal, state and international governments in promoting captive breeding and release of endangered cranes, and maintains breeding pairs of all crane species. In March 1978, a mortality event occurred at ICF resulting in the deaths of 18 of 51 cranes of 14 species. Of the 18 birds that died, 7 were threatened or endangered (5 Japanese cranes [Grus japonicus] and 2 hooded cranes [G. monachus]). Carcasses were submitted to NWHC, where a previously-unknown herpesvirus, later named inclusion body disease of cranes (IBDC), was isolated and determined to be the cause of mortality (Docherty and Henning 1980). The NWHC participated with ICF in development of on-site management actions and facility design to control this new disease, conducted additional follow-up studies (Docherty and Romaine 1983; Shuh et al. 1986), and recommended further preventive actions and national surveillance for IBDC in captive cranes (Dein and Docherty 1988). While national surveillance of captive cranes has not been adopted, serological testing of all cranes at the ICF is conducted annually to monitor for its recurrence. Further mortality from IBDC has not occurred at ICF, nor in North America. The source of the herpesvirus was not identified, but likely was introduced by recent international importation of several crane species.

In winter 1994-1995, 29 bald eagles were found dead at De Gray Lake, Arkansas. In 1996-1997, an additional 26 dead bald eagles, as well as American coots (Fulica americana), were found at the same lake and nearby Lake Oachita. These deaths represented $30-65 \%$ of the overwintering bald eagle population at these sites. Eagle carcasses (5 from 1994-1995 and 19 from 1996-1997) were 
submitted to the NWHC by the Arkansas Game and Fish Commission. Extensive diagnostic testing and histopathology led to the diagnosis of a previously undescribed syndrome, termed avian vacuolar myelinopathy (AVM) (Thomas et al. 1998). Syndromic surveillance was initiated across the southeastern US, and by 1999 AVM was identified in bald eagles, waterfowl, and several other avian species in North Carolina and South Carolina, continues to occur sporadically at these locations, and has now been documented in Georgia and Texas (Fischer et al. 2002). While the specific etiology causing AVM is still to be confirmed, field and laboratory studies by the NWHC (Rocke et al. 2005), the Southeastern Cooperative Wildlife Diseases Study and others (Birrenkott et al. 2004; Wilde et al. 2005) have implicated a biotoxin produced by algae associated with the exotic aquatic plant Hydrilla verticillata.

White-nose syndrome (WNS) in bats, caused by a newly discovered fungal pathogen, Pseudogymnoascus (formerly Geomyces) destructans, has emerged as one of the most devastating wildlife diseases in North America. This disease has rapidly spread from its original site of discovery in a cave in New York in 2006 to now include 22 states and five Canadian provinces (www.whitenosesyndrome.org/ about/where-is-it-now) where it has killed an estimated 5.7-6.7 million cave-dwelling bats during hibernation (Froschauer 2012). This cold-loving fungus was first isolated at NWHC, where Koch's postulates were fulfilled and its pathogenesis described (Blehert et al. 2009; Cryan et al. 2010; Lorch et al. 2011; Meteyer et al. 2012). Its impact on the once-common little brown bat (Myotis lucifugus) in Northeastern U.S. has been the greatest, where Frick et al. (2010) suggest this species may now face regional extinction. Additionally, WNS has been diagnosed at NWHC in endangered Indiana (M. sodalis) and gray (M. grisescens) bats (NWHC unpublished). The USFWS has issued a notice of petition finding and initiation of status review to list the eastern small-footed (M. leibii) and the northern longeared (M. septentrionalis) bats in response to concern over the impact of WNS (USFWS 2011).

\section{Discussion}

Evidence for the role of disease in the population decline to threatened or endangered status and extinction of wildlife species, and in inhibiting population recovery, has appeared to have increased in recent decades. In most of the described cases, an introduced or emerging disease or vector is the proximate cause. Identification and quantification of mortality factors at this stage can contribute to management and regulatory decisions that may enhance survival and recovery of a species.

Through diagnostic studies of $>16,000$ submissions of specimens from candidate, threatened, and endangered species, the NWHC has contributed importantly to the knowledge of causes of morbidity and mortality and health status in these species. NWHC data, research studies, and technical expertise have often been used in management and regulatory decisions, a few cases of which are described herein. However, the NWHC diagnostic database is comprised largely of voluntary submissions of cases of morbidity or mortality by state and federal agencies, representing a form of passive surveillance. These data thus contain numerous biases that often prevent statistically meaningful inferences of the relative importance of the various causes of mortality to a population or species as a whole. Despite this drawback, the cumulative long-term information on large numbers of a wide variety of species has been valuable to wildlife and natural resource managers. Technical assistance, consultation, and expert witness provided by wildlife disease specialists at the NWHC have also been valuable in listing decisions, the development of species recovery and implementation plans, control and management of disease outbreaks, and support of law enforcement officials in protecting listed species. Finally, applied research and development activities focused on factors limiting the recovery of listed species offer the means for new and innovative opportunities to control wildlife diseases.

The NWHC is one of a number of state, federal, and university facilities that provide diagnostic support, technical assistance, and research for wildlife diseases in North America, including those of imperiled species. For example, the Canadian Cooperative Wildlife Health Centre, the Southeastern Cooperative Wildlife Disease Study at the University of Georgia, the Wildlife Health Center at the University of California at Davis, EcoHealth Alliance, and the San Diego Zoo likewise have wildlife disease programs that benefit imperiled species in North America and beyond. As threats to imperiled species continue and are likely to increase not just from emerging diseases but other anthropogenic factors affecting their health and survival, there is a great need to better integrate and coordinate efforts to identify, understand, and manage diseases as well as other morbidity and mortality factors that are driving them to extinction or preventing their recovery. However, 
there is currently no national infrastructure in the U.S. to muster the various stakeholders in wildlife health to respond to wildlife health emergencies. To that end, an effort has been recently initiated by multiple state and federal agencies and organizations, including the NWHC, to establish a National Fish and Wildlife Health Network to "build a collaborative, operational framework by which government agencies, tribes, universities and professional conservation organizations cooperate to assist tribal, state and federal agencies in their responsibilities to manage these diseases." This national network would "coordinate fish and wildlife disease surveillance, laboratory analysis, information dissemination, communication and response at a national level and across federal, state and tribal agencies and other stakeholders" (Sleeman et al. 2013).

\section{ACKNOWLEDGMENTS}

I appreciate the assistance of $\mathrm{K}$. Cunningham in the preparation of materials for this manuscript, and J.C. Franson and J.M. Sleeman for critical reviews. I also express my gratitude to the very large number of scientists and support staff at the NWHC, past and present and too numerous to mention, as well as our numerous partners in the USFWS and other agencies and facilities, for their dedication and resolve to have their science make a difference in the management of wildlife and conservation of imperiled species. Any use of trade, product, or firm names in this manuscript is for descriptive purposes and does not imply endorsement by the U.S. Government.

\section{OPEn Access}

This article is distributed under the terms of the Creative Commons Attribution License which permits any use, distribution, and reproduction in any medium, provided the original author(s) and the source are credited.

\section{REFERENCES}

Abbott RC, Osorio JE, Bunck CM, Rocke TE (2012) Sylvatic plague vaccine: a new tool for conservation of threatened and endangered species. Ecohealth 9:243-250

Antolin MF, Gober P, Luce B, Biggins DE, Van Pelt WE, Seery DB, Lockhart M, Ball M (2002) The influence of sylvatic plague on North American wildlife at the landscape level, with special emphasis on black-footed ferret and prairie dog conservation.
In: Transactions of the 67th North American Wildife and Natural Resources Conference, Rahm J (editor), Washington, DC: Wildlife Management Institute, pp 104-127

APLIC, USFWS (2005) Avian protection plan (APP) guidelines. Washington, DC: U.S. Fish and Wildlife Service, $84 \mathrm{pp}$. http://www.fws.gov/migratorybirds/CurrentBirdIssues/Hazards/ APP/AVIAN\%20PROTECTION\%20PLAN\%20FINAL\%204\% 2019\%2005.pdf. Accessed March 30, 2013

Biggins DE, Godbey JL, Gage KL, Carter LG, Montenieri JA (2010) Vector control improves survival of three species of prairie dogs (Cynomys) in areas considered enzootic for plague. Vector-Borne and Zoonotic Diseases 10:17-26

Birrenkott AH, Wilde SB, Hains JJ, Fischer JR, Murphy TM, Hope CP, Parnell PG, Bowerman WW (2004) Establishing a foodchain link between aquatic plant material and avian vacuolar myelinopathy in mallards (Anas platyrhynchos). Journal of Wildlife Diseases 40:485-492

Blehert DS, Hicks AC, Behr M, Meteyer CU, Berlowski-Zier BM, Buckles EL, Coleman JTH, Darling SR, Gargas A, Niver R, Okoniewski JC, Rudd RJ, Stone WB (2009) Bat white-nose syndrome: an emerging pathogen? Science 323:227. doi:10.1126/ science. 1163874

Breed AC, Plowright RK, Hayman DTS, Knobel DL, Molenaar FM, Gardner-Roberts D, Cleaveland S, Haydon DT, Kock RA, Cunningham AA, Sainsbury AW, Delahay RJ (2009) Disease management in endangered mammals. In: Management of disease in wild mammals, Delahay RJ, Smith GC, Hutchings MR (editors), New York, NY: Springer, pp 215-239

Carpenter JW, Watts DM, Crabbs CL, Clark GG, Scott TW, Docherty DE, Pagac BB, Dorothy JM, Olson JG, Dein FJ (1992) Prevention of eastern equine encephalitis virus in captive cranes. In: Proceedings of the 1988 North American Crane Workshop, Wood DA (editor), State of Florida Freshwater Game and Fish Commission, Nongame Wildlife Technical Report No. 12, Talahassee, FL: Florida Freshwater Game and Fish Commission, pp 211-217

Chang G-J, Davis BS, Stringfield C, Lutz C (2007) Prospective immunization of the endangered Cakifornia condors Gymnog$y$ s californianus protects this species from lethal West Nile virus infection. Vaccine 25:2325-2330

Cryan PM, Meteyer CU, Boyles JG, Blehert DS (2010) Wing pathology of white-nose syndrome in bats suggests life-threatening disruption of physiology. BMC Biology 8:135. doi:10.1186/ 1741-7007-8-135

Daszak P, Berger L, Cunningham AA, Hyatt AD, Green DE, Speare R (1999) Emerging infectious diseases and amphibian population declines. Emerging Infectious Diseases 5:735-748

Dein FJ, Docherty DE (1988) Management considerations for inclusion body disease of cranes. Wheeling, WV: American Association of Zoological Parks and Aquariums, pp 494-496

Docherty DE, Henning DJ (1980) The isolation of a herpesvirus from captive cranes with an inclusion body disease. Avian Diseases 24:278-283

Docherty DE, Romaine RI (1983) Inclusion body disease of cranes: a serological follow-up to the 1978 die-off. Avian Diseases 27:830-835

Fischer JR, Lewis LA, Augspurger T, Rocke TE (2002) Avian vacuolar myelinopathy: a newly recognized fatal neurological disease of eagles, waterfowl, and other birds. In: Transactions of the sixty-seventh North American wildlife and natural resources conference, Rahm J (editor), Washington, DC: Wildlife Management Institute, pp 51-61 
Franson JC, Sileo L, Thomas NJ (1995) Causes of eagle deaths. In: our living resources: a report to the nation on the distribution, abundance, and health of U.S. plants, animals, and ecosystems, La Roe ET, Farris GS, Puckett CE, Doran PD, Mac MJ (editors), Washington, DC: U.S. Department of Interior, National Biological Service, p 68

Frick WF, Pollock JF, Hicks AC, Langwig KE, Reynolds DS, Turner GG, Butchkoski CM, Kunz TH (2010) An emerging disease causes regional population collapse of a common North American bat species. Science 329:679-682. doi:10.1126/science. 1188594

Friend M, Franson JC, Anderson WL (2009) Biological and societal dimensions of lead poisoning in birds in the USA. In: Ingestion of Lead from Spent Ammunition: Implications for Wildlife and Humans, Watson RT, Fuller M, Hunt WG (editors), Boise, Idaho: The Peregrine Fund, pp 1-27. doi:10.4080/ ilsa.2009.0104

Froschauer, A (2012) White nose syndrome in bats: the science and uncertainty of estimating the impacts of white-nose syndrome in North American bat populations. http://wordpress. com/2012/02/14/estimating-mortality/. Accessed September 26, 2013

Glaser LC (1995) Wildlife mortality attributed to organophosphorus and carbamate pesticides. In: Our Living Resources: A Report to the Nation on the Distribution, Abundance, and Health of U.S. Plants, Animals, and Ecosystems, La Roe ET, Farris GS, Puckett CE, Doran PD, Mac MJ (editors), Washington, DC: U.S. Department of Interior, National Biological Service, pp 416-418

Grinnell GB (1894) Lead poisoning. Forest and Stream 42:117-118

Jachowski DS, Lockhart JM (2009) Reintroducing the black-footed ferret (Mustela nigripes) to the Great Plains of North America. Small Carnivore Conservation 41:58-64

Livieri TM (2013) Conata basin black-footed ferret monitoring report Summer/Fall 2012. Report submitted to the US Forest Service: Wall Ranger District, Badlands National Park, US Fish \& Wildlife Service, and South Dakota Game, Fish \& Parks. Wellington CO: Prairie Wildlife Research, 15 pp

Lorch JM, Meteyer CU, Behr MJ, Boiyles JG, Cryan PM, Hicks AC, Ballman AE, Coleman JTH, Redell DN, Blehert DS (2011) Experimental infection of bats with Geomyces destructans causes white-nose syndrome. Nature 480:376-378

MacPhee RDE, Greenwood AD (2013) Infectious disease, endangerment, and extinction. International Journal of Evolutionary Biology 2013:1-9 (Article ID 571939)

Matchett MR, Biggins DE, Carlson V, Powell B, Rocke T (2010) Enzootic plague reduces black-footed ferret (Mustela nigripes) survival in Montana. Vector-Borne and Zoonotic Diseases 10: 27-35

McCallum H, Jones M, Hawkins C, Hamede R, Lachish S, Sinn DL, Beeton N, Lazenby B (2009) Transmission dynamics of Tasmanian devil facial tumor disease may lead to disease-induced extinction. Ecology 90:3379-3392

Meteyer CU, Barber D, Mandl JN (2012) Pathology in euthermic bats with white-nose syndrome suggests a natural manifestation of immune reconstitution inflammatory syndrome. Virulence 3:583-588. doi:10.4161/viru.22330

Moulton DW, Weller MW (1984) Biology and conservation of the Laysan duck Anas laysanensis. Condor 86:105-117

Olsen GH, Turrell MJ, Pagac BB (1997) Efficacy of eastern equine encephalitis immunization in whooping cranes. Journal of Wildlife Diseases 33:312-315
Olsen GH, Miller KJ, Docherty DE, Bochsler VS, Sileo L (2009) Pathogenicity of West Nile virus and response to vaccination in sandhill cranes (Grus canadensis) using a killed vaccine. Journal of Zoo and Wildlife Medicine 40:263-271

Pedersen AB, Jones KE, Nunn CL, Altizer S (2007) Infectious diseases and extinction risk in wild mammals. Conservation Biology 21:1269-1279

Powell BS, Andrews GP, Enama JT, Jendrek S, Bolt C, Worsham P, Pullen JK, Ribot W, Hines H, Smith L, Heath DG, Adamovicz JJ (2005) Design and testing for a non-tagged F1-V fusion protein as vaccine antigen against bubonic and pneumonic plague. Biotechnology Progress 21:1490-1510

Randall DA, Williams SD, Kuzmin IV, Rupprecht CE, Tallents LA, Tefera Z, Argaw K, Shiferaw F, Knobel DL, Sillero-Zubiri C, Laurenson MK (2004) Rabies in endangered Ethiopian wolves. Emerging Infectious Diseases 10:2214-2217

Reynolds MH, Work TM (2005) Mortality in the endangered Laysan teal Anas laysanensis: conservation implications. Wildfowl 55:31-48

Reynolds MH, Seavy NE, Vekasy MS, Klavitter JL, Laniawe LP (2008) Translocation and early post-release demography of endangered Laysan teal. Animal Conservation 11:160-168

Reynolds MH, Brink KW, Laniawa L (2011) Population estimates and monitoring guidelines for endangered Laysan teal, Anas laysanensis, on Midway Atoll: pilot study results 2008-2010. Hawaii Cooperative Studies Unit Technical Report HCSU-021, Hilo HI: University of Hawai'i at Hilo, pp 1-67

Rocke TE, Thomas NJ, Meteyer CU, Quist CF, Fischer JR, Augspurger T, Ward SE (2005) Attempts to identify the source of avian vacuolar myelinopathy for waterbirds. Journal of Wildife Diseases 41:163-170

Rocke TE, Smith S, Marinari P, Kreeger J, Enama J, Powell B (2008) Vaccination with F1-V fusion protein protects blackfooted ferrets (Mustela nigripes) against plague upon oral challenge with Yersinia pestis. Journal of Wildlife Diseases 44:1-7

Rocke TE, Pussini N, Smith SR, Williamson J, Powell B, Osorio JE (2010) Consumption of baits containing raccoon pox-based vaccines protects black-tailed prairie dogs (Cynomys ludovicianus). Vector-Borne and Zoonotic Diseases 10:53-58

Rupprecht CE, Hanlon CA, Slate D (2004) Oral vaccination of wildlife against rabies: opportunities and challenges in prevention and control. Developmental Biology 119:173-184

Ryan SJ, Walsh PD (2011) Consequences of non-intervention for infectious disease in African great apes. PLoS ONE 6(12):e29030. doi:10.1371/journal.pone.0029030

Schloegel LM, Hero J, Berger L, Speare R, McDonald K, Daszak P (2006) The decline of the sharp-nosed day frog (Taudactylus acutirostris): the first documented case of extinction by infection in a free-ranging wildlife species? Ecohealth 3:35-40. doi:10.1007/ s103393-005-0012-6

Shuh JCL, Sileo L, Siegfried LM, Yuill TM (1986) Inclusion body disease of cranes: comparison of pathologic findings in cranes with acquired versus experimentally induced disease. Journal of the American Veterinary Medical Association 189:993-996

Skerratt LF, Berger L, Speare R, Cashins S, McDonald KR, Phillott AD, Hines HB, Kenyon N (2007) Spread of chytridiomycosis has caused the rapid global decline and extinction of frogs. EcoHealth 4:125-134. doi:10.1007/s10393-007-0093-5

Sleeman J, Gillin C, Rowles T, Gulland F, Chavarria G, Leighton F, Choudhury A, Rents T, Howard J, Johansen P (2013) Proposal to 
create a US National Fish and Wildlife Health Network. Presented at 2013 North American Wildlife and Natural Resource Conference, Fish and Wildlife Health Committee, held in Crystal City, VA, 2 pp

Smith KF, Sax DF, Lafferty KD (2006) Evidence for the role of infectious disease in species extinction and endangerment. Conservation Biology 20:1349-1357

Stewart A (2009) Rabies outbreak in the bale Mountains: vaccinating Ethiopian wolves [Web log post]. http://bornfree.wildlife direct.org/2009/06/19/rabies-outbreak-in-the-bale-mountains-\%E2 \%80\%93-vaccinating-ethiopian-wolves. Accessed March 30, 2013

Thomas NJ (1999) Electrocution. In: Field Manual of Wildlife Diseases: General Field Procedures and Diseases of Birds, Friend M, Franson JC (editors), Washington, DC: U.S. Department of Interior, U.S. Geological Survey, Biological Resources Division, pp 357-360

Thomas NJ, Meteyer CU, Sileo L (1998) Epizootic vacuolar myelinopathy of the central nervous system of bald eagles (Haliaeetus leucocephalus) and American coots (Fulica americana). Veterinary Pathology 35:479-487

USFWS (1976) Final environmental statement: Proposed use of steel shot for hunting waterfowl in the United States, Washington, DC: U.S. Department of Interior, U.S. Fish and Wildlife Service

USFWS (1986) Final supplemental environmental impact statement: Use of lead shot for hunting migratory birds in the United States, Washington, DC: U.S. Department of Interior, U.S. Fish and Wildlife Service

USFWS (2009) Utah prairie dog (Cynomys parvidens) draft revised recovery plan, Denver, CO: U.S. Fish and Wildlife Service
USFWS (2011) Review finds endangered species protection may be warranted for two bat species. U.S. Fish and Wildlife Service News Release June 28, 2011, Washington, DC:U.S. Fish and Wildlife Service. www.fws.gov/whitenosesyndrome/news/062811. html. Accessed April 1, 2013

Warner RE (1968) The role of introduced diseases in the extinction of the endemic Hawaiian avifauna. Condor 70:101-120

Wilcove DS, Rothstein D, Dubow J, Phillips A, Losos E (1998) Quantifying threats to imperiled species in the United States. BioScience 48:607-615

Wilde SB, Murphy TM, Hope CP, Habrun SK, Kempton J, Birrenkott A, Wiley F, Bowerman WW, Lewitis AJ (2005) Avian vacuolar myelinopathy linked to exotic aquatic plants and a novel cyanobacterial species. Environmental Toxicology 20: 348-353

Williams ES, Thorne ET, Appel MJG, Belitsky DW (1988) Canine distemper in black-footed ferrets (Mustela nigripes) from Wyoming. Journal of Wildlife Diseases 24:385-398

Wilson EO (1992) The diversity of life, Cambridge, MA: Belknap Press, pp 253

Work TM, Meteyer CU, Cole RA (2004) Mortality in Laysan ducks (Anas laysanensis) by emaciation complicated by Echinuria uncinata on Laysan Island, Hawaii, 1993. Journal of Wildlife Diseases 40:110-114

Work TM, Klavitter JL, Reynolds MH, Blehert D (2010) Avian botulism: a case study in translocated endangered Laysan ducks (Anas laysanensis) on Midway Atoll. Journal of Wildlife Diseases 46:499-506 